\title{
Sustaining productivity of a Vertosol at Warra, Queensland, with fertilisers, no-tillage or legumes. 7. Yield, nitrogen and disease-break benefits from lucerne in a two-year lucerne-wheat rotation
}

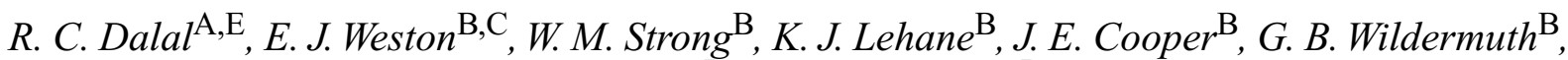 \\ A. J. King ${ }^{\mathrm{D}}$ and C. J. Holmes ${ }^{\mathrm{D}}$

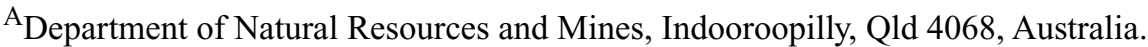 \\ ${ }^{B}$ Farming Systems Institute, Department of Primary Industries, Toowoomba, Qld 4350, Australia. \\ CPresent address: 50 Broadwater Terrace, Redland Bay, Qld 4165, Australia. \\ ${ }^{D}$ Department of Natural Resources and Mines, Toowoomba, Qld 4350, Australia. \\ ${ }^{\mathrm{E}}$ Author for correspondence; e-mail: Ram.Dalal@nrm.qld.gov.au
}

\begin{abstract}
Continuous cultivation and cereal cropping of southern Queensland soils previously supporting native vegetation have resulted in reduced soil nitrogen supply, and consequently decreased cereal grain yields and low grain protein. To enhance yields and protein concentrations of wheat, management practices involving $\mathrm{N}$ fertiliser application, with no-tillage and stubble retention, grain legumes, and legume leys were evaluated from 1987 to 1998 on a fertility-depleted Vertosol at Warra, southern Queensland. The objective of this study was to examine the effect of lucerne in a 2-year lucerne-wheat rotation for its nitrogen and disease-break benefits to subsequent grain yield and protein content of wheat as compared with continuous wheat cropping.

Dry matter production and nitrogen yields of lucerne were closely correlated with the total rainfall for October-September as well as March-September rainfall. Each $100 \mathrm{~mm}$ of total rainfall resulted in $0.97 \mathrm{t} / \mathrm{ha}$ of dry matter and $26 \mathrm{~kg} / \mathrm{ha}$ of nitrogen yield. For the March-September rainfall, the corresponding values were $1.26 \mathrm{t} / \mathrm{ha}$ of dry matter and $36 \mathrm{~kg} / \mathrm{ha}$ of nitrogen yield. The latter values were $10 \%$ lower than those produced by annual medics during a similar period. Compared with wheat-wheat cropping, significant increases in total soil nitrogen were observed only in 1990, 1992 and 1994 but increases in soil mineralisable nitrogen were observed in most years following lucerne. Similarly, pre-plant nitrate nitrogen in the soil profile following lucerne was higher by $74 \mathrm{~kg} / \mathrm{ha}$ $(9-167 \mathrm{~kg} \mathrm{~N} / \mathrm{ha})$ than that of wheat-wheat without $\mathrm{N}$ fertiliser in all years except 1996 . Consequently, higher wheat grain protein ( 7 out of 9 seasons) and grain yield (4 out of 9 seasons) were produced compared with continuous wheat. There was significant depression in grain yield in 2 (1993 and 1995) out of 9 seasons attributed to soil moisture depletion and/or low growing season rainfall. Consequently, the overall responses in yield were lower than those of $50 \mathrm{~kg} / \mathrm{ha}$ of fertiliser nitrogen applied to wheat-wheat crops, 2-year medic-wheat or chickpea-wheat rotation, although grain protein concentrations were higher following lucerne.

The incidence and severity of the soilborne disease, common root rot of wheat caused by Bipolaris sorokiniana, was generally higher in lucerne-wheat than in continuous wheat with no nitrogen fertiliser applications, since its severity was significantly correlated with plant available water at sowing. No significant incidence of crown rot or root lesion nematode was observed. Thus, productivity, which was mainly due to nitrogen accretion in this experiment, can be maintained where short duration lucerne leys are grown in rotations with wheat.
\end{abstract}

\section{Introduction}

The cereal growing areas of southern Queensland and northern New South Wales (NSW) have largely relied on native soil nitrogen $(\mathrm{N})$ fertility, which has been declining since cropping started almost 100 years ago (Hallsworth et al. 1954; Dalal and Mayer 1986a; Martin et al. 1988; Dalal and Probert 1997), resulting in static or declining crop yields and grain protein concentrations (Dalal et al. 1991). Wheat grain yield and grain protein could be improved by either $\mathrm{N}$ fertiliser applications in a continuous cereal cropping (Holford and Doyle 1992; Strong et al. 1996) or inclusion of a legume such as lucerne in rotation with wheat (Holford 1980; Littler 1984; Whitehouse and Littler 1984; Hossain et al. 1996b; Holford and Crocker 1997; Holford et al. 1998; Armstrong et al. 1999).

In southern Queensland and northern NSW, it has been shown that even a temperate annual pasture legume such as annual medics, significantly increases mineral N (mostly nitrate- $\mathrm{N}$ since ammonium- $\mathrm{N}$ concentrations are very small), grain yields and protein concentrations of subsequent wheat 
crops (Dalal et al. 1991; Hossain et al. 1996b; Holford et al. 1998; Weston et al. 2002). Therefore, it is expected that perennial legumes such as lucerne may perform better than winter growing annual medics in this region due to summer-dominant rainfall (Holford 1980; Littler 1984; Hossain et al. 1996b; Holford and Crocker 1997; Weston et al. 2000).

The $\mathrm{N}$ benefits of lucerne to the following wheat crop depends on its productivity during the ley period since the amount of $\mathrm{N}$ fixed by lucerne is closely associated with the total amount of dry matter (DM) produced; on average, $20-25 \mathrm{~kg}$ of shoot $\mathrm{N}$ is fixed for each tonne of legume herbage DM produced (Peoples and Baldock 2001). Hossain et al. (1995) found that $60 \mathrm{~kg} / \mathrm{ha}$ of $\mathrm{N}_{2}$ was fixed (estimated by $\delta^{15} \mathrm{~N}$ natural abundance technique) by lucerne in its aboveground DM at Warra, southern Queensland, in 1988. Another $50 \%$ of the legume $\mathrm{N}$ may have been present in its root biomass (Peoples and Baldock 2001; Peoples et al. 2001). Hossain et al. (1995) also found that $70 \%$ of lucerne $\mathrm{N}$ yield was derived from atmosphere. Although the proportion of $\mathrm{N}$ fixed by legumes is affected by initial soil $\mathrm{N}$ fertility (Doughton et al. 1993; Holford et al. 1998; Armstrong et al. 1999) and seasonal growing conditions, lucerne appears to fix more $\mathrm{N}$ than either annual medics or chickpeas in northern NSW and southern Queensland (Dalal et al. 1991; Hossain et al. 1995; Holford et al. 1998).

A significant benefit of lucerne ley is in its contribution to the soil total $\mathrm{N}$ and nitrate- $\mathrm{N}$ supply to subsequent wheat crops. A substantial increase in nitrate- $\mathrm{N}$ has been observed following lucerne ley (Whitehouse and Littler 1984; Hossain et al. 1996a) and this is reflected in increased $\mathrm{N}$ uptake (Holford 1980) and increased wheat grain yield and protein (Holford 1980; Whitehouse and Littler 1984; Hossain et al. $1996 b$ ). Provided plant available water is not limiting, N uptake by wheat following lucerne was found to be closely related to the nitrate-N present in soil (Holford 1980; Holford et al. 1998).

Besides $\mathrm{N}$ accretion, legumes in rotation may control or reduce the incidence and severity of soilborne cereal diseases. For example, take-all in wheat (Gaeumannomyces graminis) was negligible following a lupin (Lupinus augustifolius) crop compared with $36 \%$ incidence in wheat-wheat rotation (Reeves et al. 1984). Also, the incidence and severity of crown rot of wheat, caused by Fusarium graminearum, was reduced by rotation with chickpea in southern Queensland (Wildermuth et al. 1992). The incidence and severity of common root rot of wheat caused by Bipolaris sorokiniana following chickpea was associated with the plant available water at sowing; the percentage of wheat plants affected increased as plant available water at sowing decreased (Dalal et al. 1998). Therefore, the effect of lucerne as a disease-break crop for wheat may be tempered by its capacity to extract more water and thus leave behind larger moisture deficit than continuous wheat cropping.
Plant available water deficit could be greater as well as more frequent following lucerne ley than continuous wheat cropping (Holford and Doyle 1978), annual medics or chickpea (Holford et al. 1998), thus adversely affecting wheat yields in the north-eastern subtropical Australia. Consequently, significant amounts of mineral $\mathrm{N}$ following the longer duration lucerne ley may remain unutilised by wheat, to be subjected to leaching and denitrification losses. Also, disease-break impact of lucerne on the following wheat may be uncertain.

Since seasonal variability is a strong feature of the subtropical environment, it is necessary to measure lucerne production, fertility restoration and wheat crop yields over a longer term (>1-2 seasons) for assessing the sustainability of lucerne-wheat rotation in this region. This study aims to measure the effects of lucerne in a 2-year lucerne-wheat rotation on yields, $\mathrm{N}$, and disease-break benefits to the following wheat crop. These effects will then be compared with wheat-wheat rotations on a fertility-depleted Vertosol (Isbell 1996) $[0.06 \%$ total N compared with $0.13 \%$ total $\mathrm{N}$ for Holford (1980) and Littler (1984) lucerne trial sites on Vertosols] in 4 cycles of the rotation from 1987 to 1996.

\section{Materials and methods}

Site details

A long-term field experiment was conducted at Warra $\left(26^{\circ} 47^{\prime} \mathrm{S}\right.$, $150^{\circ} 53^{\prime} \mathrm{E}$ ) in southern Queensland on a soil that had been cultivated for cereal cropping since 1935. The soil is a Vertosol (Typic Chromustert) that has lost $70 \%$ of organic C (from 2.23 to $0.68 \%$ ) and total $\mathrm{N}$ (from 0.20 to $0.06 \%$ ) from the $0-0.1 \mathrm{~m}$ layer after 50 years (Dalal and Mayer $1986 b, 1986 c)$. Detailed description of the soil, as well as mean monthly maximum and minimum temperatures, mean monthly rainfall, and growing season rainfall at the field site (1987-98) are described in earlier papers of this series (Dalal et al.1995; Strong et al. 1996; Weston et al. 2002). Briefly, the soil contains $56 \%$ clay, $17 \%$ silt and $27 \%$ sand. It is alkaline at the surface ( $\mathrm{pH} 8.6)$ trending to strongly acidic ( $\mathrm{pH} \mathrm{4.9)}$ at $1.2 \mathrm{~m}$ depth. Annual rainfall varied from $396 \mathrm{~mm}$ in 1986 to $800 \mathrm{~mm}$ in 1998, and March-September rainfall varied from $74 \mathrm{~mm}$ in 1991 to $492 \mathrm{~mm}$ in 1998.

\section{Experimental design}

The experimental design and treatments of this experiment are described by Dalal et al. (1995). The earlier reports from this experiment contain results on the effects of fertiliser N (Strong et al. 1996), chickpea-wheat rotation (Dalal et al. 1998), and annual medic-wheat rotation (Weston et al. 2002) on wheat yield and protein. Briefly, a 2-year rotation of lucerne (Medicago sativa L. cv. Trifecta) and wheat (Triticum aestivum L. cv. Hartog) is described below. Lucerne was established in a randomised block design with 4 replications (plot size, 6.75 by $25 \mathrm{~m}$ ) in a core experiment (Table 1), which was not grazed. Pasture treatments were repeated as duplicate plots in an adjacent area where they were grazed by sheep. The lucerne leys in treatment 4 were grown in 1988, 1990, 1992 and 1994, and subsequent wheat crops were grown in 1989, 1993 and 1995. Drought in 1991 precluded the sowing of wheat following lucerne ley. In treatment 5, the lucerne leys were grown in 1989, 1991, 1993 and 1995, and subsequent wheat crops were grown in 1990, 1992, 1994 and 1996. Treatment 5 plots were sown to wheat (wheat bioassay) in 1996-98 and treatment 4 in 1997-98. 


\section{Pasture management}

Wheat was undersown with lucerne $(2 \mathrm{~kg} / \mathrm{ha})$ in 1987 to provide a lucerne ley in 1988 (treatment 4), which was followed by a wheat crop in 1989. For the second lucerne ley (treatment 5), wheat was undersown with lucerne in 1988 to provide a lucerne sward in 1989, which was followed by wheat in 1990 (Table 1). Wheat and undersown lucerne was generally sown in May or June, depending on sowing rains.

In the core experiment, ungrazed lucerne leys were harvested ('cut and remove') to a height of $0.1 \mathrm{~m}$ at 3-monthly sampling intervals (December, March, June and September); while in the adjacent experiment, lucerne was grazed by sheep to a similar height during the 4 weeks before sampling. Dry matter yield in the grazed lucerne was assessed by harvesting lucerne from movable exclosures at 3-monthly intervals. In both experiments, from each replicate plot, 5 quadrats of $1 \times 1 \mathrm{~m}$ were used for sampling for lucerne DM yield. At the termination of the lucerne ley in October, an additional DM measurement was made. Plant material was dried at $75^{\circ} \mathrm{C}$, weighed and ground to pass through a $1 \mathrm{~mm}$ sieve and DM \%N determined by Kjeldahl analysis (Crooke and Simpson 1971).

To coincide with the maturity and removal of annual legumes (annual medics, chickpea) (Dalal et al. 1995) and allow sufficient time for soil profile water recharge, lucerne leys were terminated in early October by blade ploughing to $0.10-0.15 \mathrm{~m}$ depth. Weed growth was controlled during the fallow period by $2-3$ ploughings to $\sim 0.1 \mathrm{~m}$ depth.

\section{Crop and soil management}

After fallow, wheat was sown at $0.25 \mathrm{~m}$ spacing at a rate of $40 \mathrm{~kg} / \mathrm{ha}$ in May or June; or $50 \mathrm{~kg} / \mathrm{ha}$ when sown in July (1990, 1993). Little weed control was required during wheat cropping, and undersown lucerne contributed only a small amount of DM and $\mathrm{N}$ to the overall rotation. Weed growth after wheat harvest during the fallow period was controlled by 2-3 ploughings (Strong et al. 1996); similar to that after the termination of the leys. Wheat crop received annually a basal rate of $10 \mathrm{~kg}$ of phosphorus as superphosphate, fortified with copper and zinc at sowing. Lucerne leys were topdressed with the same fertiliser at the same rate annually.

Just before harvest, aboveground DM yields of wheat were estimated by harvesting $1 \mathrm{~m}$ lengths of 2 adjacent plant rows, and then drying at $75^{\circ} \mathrm{C}$. Grain and straw were separated, and from their mass, harvest index was calculated. Wheat grain yields were measured from machine harvesting 1.75 by about $23 \mathrm{~m}$ of the central area of each plot. Grain yields were adjusted to $12 \%$ moisture content and grain and straw
$\% \mathrm{~N}$ determined by Kjeldahl digestion followed by automated ammonium analysis (Crooke and Simpson 1971).

Nitrogen fixation by lucerne was estimated in 1988 and 1992 ( 2 contrasting seasons) using the ${ }^{15} \mathrm{~N}$ natural abundance (Ledgard and Peoples 1988) technique. Milk thistle (Sonchus oleraceus L.) was used as a reference plant (Hossain et al. 1995; Dalal et al. 1997a).

\section{Soil sampling and analysis}

In May (presowing) and November (after harvest) each year, soil was sampled to a depth of $1.5 \mathrm{~m}$ for soil water and nitrate contents using a 50-mm diameter tube hydraulic sampler. Two soil cores taken from each plot were bulked by $0.1-\mathrm{m}$ layers to a depth of $0.3 \mathrm{~m}$ and by $0.3-\mathrm{m}$ layers below to a depth of $0.3 \mathrm{~m}$. Soil samples were stored in airtight bags at $4^{\circ} \mathrm{C}$ until analysis. Soil moisture content was determined gravimetrically by drying soil samples at $105^{\circ} \mathrm{C}$ for $48 \mathrm{~h}$ and converted to volumetric soil moisture content ( $\mathrm{mm} / \mathrm{layer}$ ) using a bulk density adjusted for the soil moisture content for the layer (Strong et al. 1996). For nitrate analysis, soil was dried at $35^{\circ} \mathrm{C}$ under draught, and ground to $<2 \mathrm{~mm}$ for colorimetric determination of nitrate (Best 1976) after extraction of $10 \mathrm{~g}$ of soil in $100 \mathrm{~mL}$ of $2 \mathrm{~mol} / \mathrm{L} \mathrm{KCl}$.

Ten cores were collected annually in May from 0 to $0.1 \mathrm{~m}$ depth from each plot, bulked together, air-dried and then analysed for mineralisable-N $(<2 \mathrm{~mm}$ size $)$. This was done using the waterlogged procedure of Waring and Bremner (1964), and total-N $(<0.25 \mathrm{~mm}$ size) by modified Kjeldahl method (Dalal et al. 1984).

\section{Disease assessment}

The incidence and severity of common root rot and crown rot of wheat were assessed from 50 randomly collected wheat plants with their roots from each plot at anthesis. The subcrown internode of each plant was examined for the extent of lesions due to common root rot. Based on subcrown internode surface covered by lesions, the wheat plants were segregated into 6 disease categories: (i) no lesion; (ii) 1 and 2 lesions covering $<10 \%$; (iii) lesions covering 10-25\%; (iv) lesions covering 25-50\%; (v) lesions covering 50-99\%; and (vi) lesions covering $100 \%$. Then disease severity was calculated from the following formula:

$$
\text { Disease severity }(\%)=\left[\left(2 \mathrm{~N}_{1}+5 \mathrm{~N}_{2}+10 \mathrm{~N}_{3}\right) \times 100\right] /
$$

$(10 \times$ total number of plants $)$,

where $\mathrm{N}_{1}$ is the number of plants in categories (ii) and (iii), $\mathrm{N}_{2}$ is the number of plants in category (iv), and $\mathrm{N}_{3}$ is the number of plants in categories (v) and (vi) (Wildermuth et al. 1992).

Table 1. Sequence of lucerne and wheat in a 2-year lucerne-wheat rotation commencing in 1988 (treatment 4 ) and 1989 (treatment 5), compared with wheat-wheat rotation without fertiliser application

$\mathrm{W}_{\mathrm{l}}$, undersown lucerne; L, lucerne ley; W, wheat; Drought, wheat not sown due to drought In 1997 and 1998, wheat was sown to assay residual nitrate-N

\begin{tabular}{lccc}
\hline Year & $\begin{array}{c}\text { Treatment } 4 \\
\text { Lucerne-wheat rotation }(0 \mathrm{~kg} \mathrm{~N} / \mathrm{ha})\end{array}$ & $\begin{array}{c}\text { Treatment } 5 \\
\text { Lucerne-wheat rotation }(0 \mathrm{~kg} \mathrm{~N} / \mathrm{ha})\end{array}$ & $\begin{array}{c}\text { Treatment } 10 \\
\text { Wheat-wheat rotation }(0 \mathrm{~kg} \mathrm{~N} / \mathrm{ha})\end{array}$ \\
\hline 1987 & $\mathrm{~W}_{1}$ & $\mathrm{~W}$ & $\mathrm{~W}$ \\
1988 & $\mathrm{~L}$ & $\mathrm{~W}_{1}$ & $\mathrm{~W}$ \\
1989 & $\mathrm{~W}_{1}$ & $\mathrm{~L}$ & $\mathrm{~W}$ \\
1990 & $\mathrm{~L}$ & $\mathrm{~W}_{1}$ & $\mathrm{~W}$ \\
1991 & Drought & $\mathrm{L}$ & Drought \\
1992 & $\mathrm{~L}$ & $\mathrm{~W}$ & $\mathrm{~W}$ \\
1993 & $\mathrm{~W}_{1}$ & $\mathrm{~L}$ & $\mathrm{~W}$ \\
1994 & $\mathrm{~L}$ & $\mathrm{~W}$ & $\mathrm{~W}$ \\
1995 & $\mathrm{~W}_{1}$ & $\mathrm{~L}$ & $\mathrm{~W}$ \\
1996 & $\mathrm{~L}$ & $\mathrm{~W}$ & $\mathrm{~W}$ \\
1997 & $\mathrm{~W}$ & $\mathrm{~W}$ & $\mathrm{~W}$ \\
1998 & $\mathrm{~W}$ & $\mathrm{~W}$ & $\mathrm{~W}$ \\
\hline
\end{tabular}


Incidence of crown rot was assessed by examining the first internode of tillers for honey brown to dark brown discoloration. Root lesion nematode effects were assessed from root lesion nematodes (Pratylenchus thornei) present in soil in May in 1988 (Wildermuth et al. 1997). None were found and hence no further assessments were made in subsequent years.

\section{Results}

Above ground dry matter production and nitrogen yield

Dry matter and $\mathrm{N}$ yields between the ungrazed (core experiment) and the grazed lucerne leys were not significantly different (data not shown). Hossain et al. (1995, $1996 a, 1996 b$ ) also found no difference in lucerne DM and $\mathrm{N}$ yields between the ungrazed and grazed lucerne leys in the first 2 rotation cycles. Therefore, only the results for the ungrazed lucerne leys are presented.

Annual DM yields of lucerne ley ranged from $0.65 \mathrm{t} / \mathrm{ha}$ in 1991 to 5.79 t/ha in 1988 (Table 2). Similarly, total N yield varied from $18 \mathrm{~kg} \mathrm{~N} / \mathrm{ha}$ in 1991 to $152 \mathrm{~kg} \mathrm{~N} / \mathrm{ha}$ in 1988 . Undersown lucerne made only a small contribution to DM yield in the cropping years, with $\mathrm{N}$ yields less than $8 \mathrm{~kg} \mathrm{~N} /$ ha.year (data not shown).

For October-September rainfall, lucerne DM and $\mathrm{N}$ yields increased by $9.7 \mathrm{~kg} \mathrm{DM} / \mathrm{ha} . \mathrm{mm}$ rainfall $\left(r^{2}=0.76\right)$ and $0.26 \mathrm{~kg} \mathrm{~N} / \mathrm{ha} . \mathrm{mm}$ rainfall $\left(r^{2}=0.86\right)$. September lucerne harvest provided the highest DM yield in most years.

The amount of DM removed from the lucerne plots from lucerne cut and remove treatment varied from $0.18 \mathrm{t} / \mathrm{ha}$ in 1991 to $2.5 \mathrm{t} / \mathrm{ha}$ in 1988 . On average, $25 \mathrm{~kg} \mathrm{~N} / \mathrm{ha}$.year $(0-58 \mathrm{~kg} \mathrm{~N} / \mathrm{ha})$ was removed in lucerne harvest ('cut and remove') during 1988-95 (Table 2).

\section{Total soil nitrogen and mineralisable-nitrogen}

For treatment 4 (commenced in 1998), the amounts of soil total $\mathrm{N}$ were significantly higher after the lucerne ley than the wheat-wheat rotation (Fig. 1a) in 1990, 1992 and 1994, with the increase in soil total $\mathrm{N}$ varying from $109 \mathrm{~kg} / \mathrm{ha}$ to $123 \mathrm{~kg} / \mathrm{ha}$. Following lucerne ley in treatment 5 however, no significant increase in soil total $\mathrm{N}$ was observed, mainly due to low rainfall seasons. Using ${ }^{15} \mathrm{~N}$ natural abundance

Table 2. Total aboveground dry matter (DM) and nitrogen yields $(\mathrm{kg} / \mathrm{ha})$ of lucerne in lucerne-wheat rotations

\begin{tabular}{lccc}
\hline Year & $\begin{array}{c}\text { DM yield } \\
(\mathrm{t} / \mathrm{ha})\end{array}$ & $\begin{array}{c}\text { DM N yield } \\
(\mathrm{kg} \mathrm{N} / \mathrm{ha})\end{array}$ & $\begin{array}{c}\text { Cut and remove N } \\
(\mathrm{kg} \mathrm{N} / \mathrm{ha})\end{array}$ \\
\hline 1988 & 5.79 & 152 & 57.9 \\
1989 & 3.57 & 114 & 36.3 \\
1990 & 2.81 & 94 & 50.0 \\
1991 & 0.65 & 18 & 4.7 \\
1992 & 1.46 & 57 & 14.4 \\
1993 & 1.35 & 45 & 8.4 \\
1994 & 2.28 & 62 & 28.2 \\
1995 & 0.81 & 24 & 0 \\
Mean & 2.34 & 71 & 25.0 \\
1.s.d. $(P=0.05)$ & 0.36 & 12 & 21.6 \\
\hline
\end{tabular}

technique for 2 contrasting seasons in treatment 4 , the amount of $\mathrm{N}$ derived from atmosphere (Ndfa) by lucerne was $103 \mathrm{~kg} \mathrm{~N} / \mathrm{ha}(68 \% \mathrm{Ndfa})$ in 1988 and $14 \mathrm{~kg} \mathrm{~N} / \mathrm{ha}(26 \% \mathrm{Ndfa})$ in 1992. The latter lucerne ley followed a no-wheat crop season (drought) in 1991 when mineral-N accumulated in the soil, and that reduced $\mathrm{N}_{2}$ fixation (Doughton et al. 1993). Also, there was lower lucerne DM yield in 1992 than in 1988 (Table 2).

Mineralisable-N was also significantly higher after the lucerne ley than the wheat-wheat rotations (Fig. 1b) in all years except in 1992 and 1994. Mineralisable-N increases ranged from 15 to $34 \mathrm{~kg} / \mathrm{ha}$. Mineralisable-N, therefore, was a more sensitive indicator than soil total $\mathrm{N}$, thus demonstrating the ability of lucerne to increase the supply of potentially available $\mathrm{N}$ in soil.

\section{Nitrate-nitrogen}

The amount of nitrate-N (0-1.2 m depth) accumulated at the end of the fallow period in May ranged from 35 to $89 \mathrm{~kg}$ $\mathrm{N} / \mathrm{ha}$ in the wheat-wheat rotations compared with 40 to $202 \mathrm{~kg} \mathrm{~N} / \mathrm{ha}$ following the lucerne leys (Table 3). Differences between the 2 treatments ranged from nil in 1996 to $167 \mathrm{~kg} \mathrm{~N} / \mathrm{ha}$ in 1993 . On average, nitrate-N after the lucerne ley was $74 \mathrm{~kg} / \mathrm{ha}$ greater than in the wheat-wheat rotations over the 8-year period (1989-96). In the initial years of this experiment, nitrate- $\mathrm{N}$ accumulated to very high levels following good lucerne growth during 1988-90, but in the later drier years, it was due to low $\mathrm{N}$ removal associated with poorer wheat growing seasons during 1993-95. Increases in

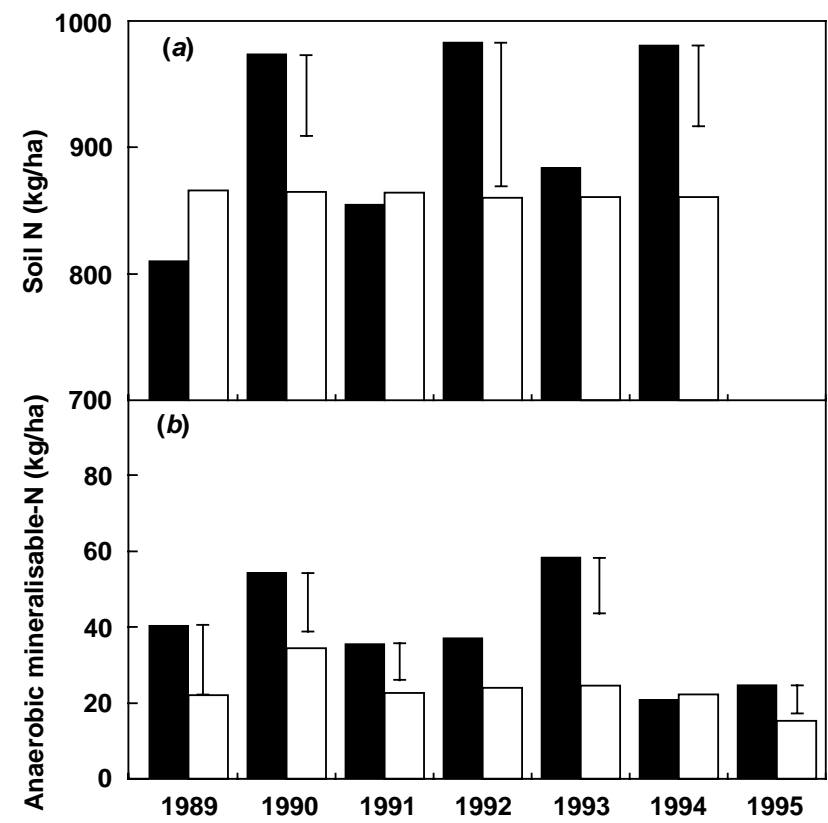

Figure 1. (a) Total soil nitrogen $(b)$ and mineralisable-nitrogen after lucerne (solid bars) in lucerne-wheat rotations and wheat-wheat rotation (open bars) with $0 \mathrm{~kg} \mathrm{~N} / \mathrm{ha}$ fertiliser application. The bar heights represent the 1.s.d. at $P=0.05$ between treatments. 
soil nitrate-N were observed down to $0.9 \mathrm{~m}$ depth early in the rotation years (Fig. 2). When wheat crops were grown in better seasons and produced higher grain yields, they extracted more plant available $\mathrm{N}$; thus, generally resulting in lower nitrate- $\mathrm{N}$ accumulation.

\section{Plant available soil water}

At wheat sowing in May, available soil water (0-1.2 m depth) in lucerne-wheat rotations was significantly lower in 1989, 1993, 1995 and 1996 than in wheat-wheat rotations (Table 3). Even in seasons when total plant available water was similar in both rotations, its distribution within the soil profile differed (Fig. 2). For example, in 1990, 1991, 1992 and 1994, significantly lower soil water contents were observed in deeper layers, usually at 0.9-1.2 $\mathrm{m}$ and 1.2-1.5 $\mathrm{m}$ depths (Fig. 2). This is consistent with greater water removal by lucerne, especially from deeper layers, and then followed by higher grain yields. On average, $27 \mathrm{~mm}$ less water was present in the lucerne-wheat rotations than in the wheat-wheat rotations, usually in layers below $0.6 \mathrm{~m}$ depth.

\section{Wheat grain yields and grain protein concentrations}

Wheat grain yield increased significantly following lucerne in 1990, 1994, 1996 and 1998 compared with the wheat-wheat rotations with no $\mathrm{N}$ fertiliser (Table 4). However, lower grain yields were obtained in 1993 and 1995 compared with the wheat-wheat rotations with no $\mathrm{N}$ fertiliser. In these 2 cropping seasons, plant available water at sowing was less than $80 \mathrm{~mm}$ (Table 3).

Wheat grain protein concentrations in lucerne-wheat rotation were significantly higher than those from the wheat-wheat rotation without $\mathrm{N}$ fertiliser in all years except in 1992 and 1996 (Table 5). Increases in grain protein concentration following lucerne ley ranged from 4 to $96 \%$ (Table 5).

\section{Incidence and severity of common root rot and crown rot}

Although common root rot occurred in all years in both lucerne-wheat and wheat-wheat rotations, its incidence and severity varied (Table 6). The lowest incidence of common root rot (23\%) occurred in the wheat-wheat rotation in 1992 and the highest incidence of common root rot (93\%) was observed in lucerne-wheat rotation in 1993. However, significant differences in the incidence of common root rot were found only in 1990 and 1993; in both of these years, the incidence was higher in lucerne-wheat rotation than that in wheat-wheat rotation. The lucerne-wheat rotation also recorded the lowest (10\% in 1989) and the highest $(68 \%$ in $1993)$ severity of common root rot of wheat. However, the severity of common root rot was similar in both rotations in all years except in 1990, when it was significantly higher in lucerne-wheat rotation compared with wheat-wheat rotation.

Crown rot of wheat was not detected in this experiment until 1995; even then the incidence and severity of crown rot were negligible in this and subsequent years. Root lesion nematodes were not observed at this site.

\section{Discussion}

\section{Lucerne yield and soil nitrogen}

Dry matter yield response to similar rainfall during the lucerne ley season (October-September) of $9.7 \mathrm{~kg} / \mathrm{mm}$ of lucerne DM in this study compares favourably with that observed by Lloyd and Hilder (1978) at Kingsthorpe $(5.5-11.9 \mathrm{~kg} / \mathrm{mm}$ of lucerne DM). Significant increase in total N (109-123 kg N/ha) was found following lucerne. Holford (1981) also found an estimated increase of $140 \mathrm{~kg} \mathrm{~N} /$ ha.year, even though initial soil N levels were high in this study $(0.13 \%$ v. $0.06 \%)$. Whitehouse and Littler (1984) measured similar increases in soil $\mathrm{N}$, that is, $\sim 130 \mathrm{~kg} \mathrm{~N} /$ ha.year in the first 2 years but no further increases after 2 years of lucerne ley. Similarly in Central Queensland, soil total $\mathrm{N}$ did not increase after 2 years although soil $\mathrm{N}$ increases were only $120 \mathrm{~kg} \mathrm{~N} / \mathrm{ha}$ (Armstrong et al. 1999). These values were measured in the top 0.1 or $0.15 \mathrm{~m}$ layer. Significant increases in total $\mathrm{N}$ may also be found below these depths (Holford et al. 1998) although Whitehouse and Littler (1984), Hossain et al. (1996a) and Dalal et al. (1995) did not find a significant increase in total $\mathrm{N}$ below $0.1 \mathrm{~m}$ depth following lucerne as compared to wheat-wheat rotation.

Table 3. Soil nitrate-nitrogen (0-1.2 m) and plant available water (0-1.2 $\mathrm{m})$ in May (pre-sowing time) following 6 months of fallow after lucerne in lucerne-wheat rotation and wheat-wheat rotation without fertiliser $\mathbf{N}$

\begin{tabular}{lcccccc}
\hline Year & \multicolumn{3}{c}{ Nitrate-N (kg/ha) } & \multicolumn{3}{c}{ Plant available water (mm) } \\
& Lucerne-wheat & Wheat-wheat & 1.s.d. $(P=0.05)$ & Lucerne-wheat & Wheat-wheat & 1.s.d. $(P=0.05)$ \\
\hline 1989 & 116 & 35 & 15 & 150 & 195 & 35 \\
1990 & 142 & 38 & 22 & 143 & 165 & n.s. \\
1991 & 123 & 38 & 36 & 81 & 95 & n.s. \\
1992 & 98 & 89 & n.s. & 127 & 151 & n.s. \\
1993 & 202 & 35 & 55 & 58 & 85 & 25 \\
1994 & 85 & 47 & 30 & 167 & 176 & n.s. \\
1995 & 169 & 62 & 53 & 76 & 124 & 26 \\
1996 & 40 & 40 & n.s. & 144 & 168 & 23 \\
Mean & 122 & 48 & 32 & 118 & 145 & 23 \\
\hline
\end{tabular}


Significant increases in mineralisable- $\mathrm{N}$ following lucerne (15-35 kg N/ha) showed that 1 year of lucerne ley provides significant $\mathrm{N}$ benefits although these may not be evident in total $\mathrm{N}$ values in some years. These increases in mineralisable-N were similar to those reported by Hossain et al. (1996a). Dalal and Mayer (1987) also observed that mineralisable-N was a sensitive indicator of changes in soil $\mathrm{N}$ fertility.

\section{Wheat yield and protein benefits following lucerne ley}

The overall yield benefits of lucerne were only marginally better $(8 \%)$ in lucerne-wheat rotation than wheat-wheat rotations without $\mathrm{N}$ fertiliser during 1989-98. However, this included both good and poor cropping seasons; the best yield increase $(>50 \%)$ was obtained in 1990 , and the worst yield decrease $(<50 \%)$ was obtained in 1995 . Similar results were obtained by Holford and Doyle (1978) for 1970 and 1971 on a Vertosol in northern NSW, irrespective of the duration of lucerne ley. Thus, the lucerne-wheat rotations in this study exacerbated the grain yield variability, from 0.5 to $3.4 \mathrm{t} / \mathrm{ha}$. In comparison, the wheat-wheat rotations without fertiliser $\mathrm{N}$ varied from 1 to $3.5 \mathrm{t} / \mathrm{ha}$; and wheat-wheat rotations with $50 \mathrm{~kg} \mathrm{~N} / \mathrm{ha}$ fertiliser application, from 0.8 to $3.7 \mathrm{t} / \mathrm{ha}$ (Table 4). Compared to the lucerne-wheat rotation, the average benefits in wheat yield in annual medics-wheat rotation, chickpea-wheat rotation, and wheat-wheat rotation
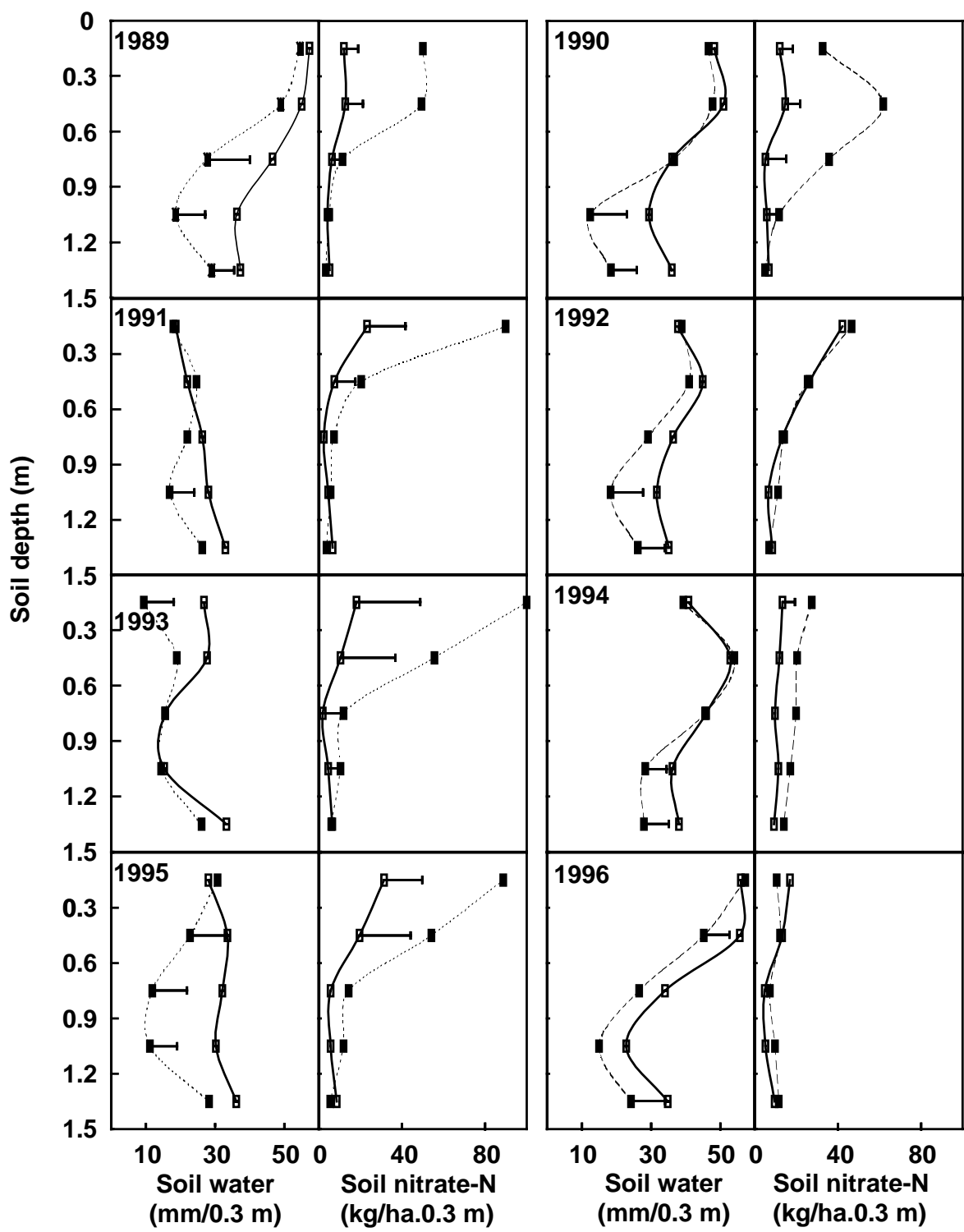

Figure 2. Depth-distribution of plant available water and nitrate-nitrogen in the soil in May (pre-sowing for wheat), measured after 6 months summer fallow following lucerne leys in lucerne-wheat rotation ( $\square$ ) and wheat-wheat rotation with $0 \mathrm{~kg} \mathrm{~N} /$ ha fertiliser application $(\square)$. Horizontal bars represent 1.s.d. at $P=0.05$. 
Table 4. Wheat grain yield (t/ha) in lucerne-wheat rotations, compared with medic-wheat, with and without $\mathbf{N}$-fertilised wheat-wheat rotations

\begin{tabular}{lccccc}
\hline Year & $\begin{array}{c}\text { Lucerne-wheat } \\
(0 \mathrm{~kg} \mathrm{~N} / \mathrm{ha})\end{array}$ & $\begin{array}{c}\text { Wheat-wheat } \\
(0 \mathrm{~kg} \mathrm{~N} / \mathrm{ha})\end{array}$ & $\begin{array}{c}\text { Medic-wheat }^{\mathrm{A}}(0 \mathrm{~kg} \mathrm{~N} / \mathrm{ha}) \\
(50 \mathrm{~kg} \mathrm{~N} / \mathrm{ha})\end{array}$ & $\begin{array}{c}\text { Wheat-wheat }^{\mathrm{B}} \\
(P=0.05)\end{array}$ \\
\hline 1989 & 1.86 & 2.07 & 2.70 & 2.82 & 0.27 \\
1990 & 3.38 & 2.23 & 3.59 & 3.14 & 0.27 \\
1991 & \multicolumn{2}{c}{ Drought year with no wheat crop sown } & & \\
1992 & 3.40 & 3.48 & 3.85 & 3.72 & ..s. \\
1993 & 1.28 & 1.88 & 1.33 & 1.88 & 0.20 \\
1994 & 1.70 & 1.02 & 1.34 & 1.58 & 0.20 \\
1995 & 0.50 & 1.20 & 0.49 & 0.80 & 0.20 \\
1996 & 2.62 & 2.27 & 4.17 & 3.79 & 0.34 \\
1997 & 2.44 & 2.11 & 2.79 & 2.21 & 0.37 \\
1998 & 1.93 & 1.40 & 2.18 & 1.71 & 0.38 \\
Mean & 2.12 & 1.96 & 2.63 & 2.41 & 0.35 \\
\hline
\end{tabular}

${ }^{\mathrm{A}}$ Weston et al. (2002). $\quad{ }^{\mathrm{B}}$ Strong et al. (1996).

with $50 \mathrm{~kg} \mathrm{~N} / \mathrm{ha}$.year fertiliser applications were $40 \%$ (Dalal et al. 1998), 25\% (Weston et al. 2002), and 10\% (Table 4), respectively. Holford and Crocker (1997), however, recorded higher wheat yields following lucerne (average $=3.5 \mathrm{t} / \mathrm{ha}$ ) than annual medics $(2.87 \mathrm{t} / \mathrm{ha})$ or chickpea $(2.59 \mathrm{t} / \mathrm{ha})$; possibly in good wheat cropping seasons.

In spite of the grain yield differences, water use efficiency $\{\mathrm{kg}$ grain $/ \mathrm{ha} . \mathrm{mm}=$ grain yield in $\mathrm{kg} / \mathrm{ha} /[$ (soil water at sowing - soil water at harvest in $0-1.2 \mathrm{~m}$ depth) + in-crop rainfall] \} was essentially similar in lucerne-wheat $(9.9 \pm 4.9)$, annual medic-wheat $(9.8 \pm 4.9)$ (Weston et al. 2002), chickpea-wheat $(11.3 \pm 3.2)$ (Dalal et al. 1998) and wheat-wheat rotations with $50 \mathrm{~kg} \mathrm{~N} /$ ha.year fertiliser application $(10.6 \pm 4.4)$ but tended to be higher than wheat-wheat rotation without fertiliser application (8.4 \pm 4.0 ) during 1989-96 (data not shown). Thus, plant available water was used as efficiently in lucerne-wheat rotation as, for example, in annual medics-wheat rotation.
In spite of the large wheat yield variability in lucerne-wheat rotations, grain protein concentrations were always higher (average protein $=13.1 \%$ ) than in wheat-wheat rotations without fertiliser $\mathrm{N}$ application (9.7\%). They were also higher than those obtained in wheat-wheat rotations with $50 \mathrm{~kg} \mathrm{~N} /$ ha.year of fertiliser $(12.1 \%)$ (Table 5), annual medics-wheat rotation (12.9\%) (Weston et al. 2002) or chickpea-wheat rotation (10.7\%) (Dalal et al. 1998). In 1989, 1993 and 1995, wheat grain proteins exceeded $15 \%$, with the consequence of low grain size (high screening leading to downgrading of grain). For example, in 1995, wheat grain of $16 \%$ protein concentration weighed $23 \mathrm{mg} / \mathrm{seed}$ from lucerne-wheat rotations compared with $36 \mathrm{mg} / \mathrm{seed}$ in wheat-wheat rotations without $\mathrm{N}$ fertiliser. However, high protein and low grain weight wheat could be blended with low protein/high grain weight on-farm to maximise economic returns from high protein wheat.

Table 5. Wheat grain protein $(\%)$ in lucerne-wheat rotations, compared with medic-wheat, with and without $\mathrm{N}$-fertilised wheat-wheat rotations

\begin{tabular}{lccccc}
\hline Year & $\begin{array}{c}\text { Lucerne-wheat } \\
(0 \mathrm{~kg} \mathrm{~N} / \mathrm{ha})\end{array}$ & $\begin{array}{c}\text { Wheat-wheat }(0 \\
\mathrm{kg} \mathrm{N} / \mathrm{ha})\end{array}$ & $\begin{array}{c}\text { Medic-wheat } \\
(0 \mathrm{~kg} \mathrm{~N} / \mathrm{ha})\end{array}$ & $\begin{array}{c}\text { Wheat-wheat }^{\mathrm{B}} \\
(50 \mathrm{~kg} \mathrm{~N} / \mathrm{ha})\end{array}$ & $\begin{array}{c}\text { 1.s.d. } \\
(P=0.05)\end{array}$ \\
\hline 1989 & 15.7 & 8.0 & 13.2 & 10.7 & 0.8 \\
1990 & 13.0 & 8.3 & 12.1 & 10.0 & 0.8 \\
1991 & \multicolumn{2}{c}{ Drought year with no wheat crop sown. } & & \\
1992 & 11.6 & 10.8 & 12.7 & 12.7 & 1.0 \\
1993 & 16.1 & 9.6 & 16.3 & 15.1 & 0.6 \\
1994 & 11.4 & 8.7 & 12.1 & 11.2 & 1.0 \\
1995 & 16.0 & 11.8 & 15.6 & 14.4 & 0.6 \\
1996 & 10.6 & 10.2 & 12.6 & 12.2 & 0.9 \\
1997 & 11.7 & 9.0 & 11.8 & 11.0 & 1.1 \\
1998 & 11.9 & 10.6 & 11.9 & 11.5 & 0.6 \\
Mean & 13.1 & 9.7 & 12.9 & 12.1 & 0.8 \\
\hline
\end{tabular}

${ }^{\mathrm{A}}$ Weston et al. (2002). $\quad{ }^{\mathrm{B}}$ Strong et al. (1996). 
Table 6. Incidence and severity of common root rot in wheat crop in lucerne-wheat rotation and wheat-wheat rotation at anthesis

\begin{tabular}{lcccccc}
\hline Year & Lucerne-wheat & $\begin{array}{c}\text { Incidence (\%) } \\
\text { Wheat-wheat }\end{array}$ & 1.s.d. $(P=0.05)$ & Lucerne-wheat & $\begin{array}{c}\text { Severity (\%) } \\
\text { Wheat-wheat }\end{array}$ & 1.s.d. $(P=0.05)$ \\
\hline 1989 & 30.6 & 26.6 & n.s. & 10.0 & 11.9 & n.s. \\
1990 & 46.2 & 24.6 & 11.1 & 32.5 & 14.8 & 10.8 \\
1992 & 35.1 & 23.1 & n.s. & 22.8 & 13.5 & n.s. \\
1993 & 92.7 & 80.8 & 11.6 & 68.4 & 61.8 & n.s. \\
1994 & 55.5 & 41.1 & n.s. & 19.0 & 11.7 & n.s. \\
1995 & 23.7 & 34.1 & n.s. & 13.8 & 22.9 & n.s. \\
1996 & 47.8 & 46.3 & n.s. & 13.3 & 18.2 & n.s. \\
Mean & 47.4 & 40.6 & n.s. & 25.7 & 22.1 & n.s.
\end{tabular}

Wheat grain yields for all years were poorly correlated with pre-sowing plant available water or soil nitrate concentrations (Tables 3 and 4), especially following lucerne ley. This was possibly due to water limitations to crop yield in some years. However, wheat grain protein (Table 5) was closely correlated with the ratio of plant available water to nitrate-N $\left(r^{2}=0.80\right)$ using relationships developed by Dalal et al. (1997b). Thus, impact of plant available water as well as nitrate- $\mathrm{N}$ must be considered following lucerne in lucerne-wheat rotations.

In most years, the plant available water (generally below $0.6 \mathrm{~m}$ depth) following lucerne was lower than in wheat-wheat rotations (Fig. 2). On average, it was also lower (118 $\mathrm{mm}$ in $0-1.2 \mathrm{~m}$ depth of soil) than chickpea-wheat rotation $(163 \mathrm{~mm})$ (Dalal et al. 1998) or annual medics-wheat rotation $(142 \mathrm{~mm})$ (Weston et al. 2002). Consequently, in extremely dry years (e.g. 1993 and 1995), wheat yields following lucerne were lower than those in the monoculture wheat without additional $\mathrm{N}$, although grain protein concentrations were $16 \%$ and above. The very high levels of accumulated nitrate- $\mathrm{N}$ may have been detrimental to wheat yields during low rainfall cropping seasons (van Herwaarden et al. 1998). Holford and Doyle (1978) and Holford et al. (1998) also observed that a black Vertosol at Tamworth did not wet to field capacity 2.5 years after the termination of lucerne ley. They suggested that lucerne must be ploughed out before January if a severe reduction in grain yield of the following wheat crop is to be minimised. In this experiment, although lucerne ley was terminated in early October, dry seasons during the fallow and cropping in some years still had adverse effects on wheat yields.

\section{Incidence and severity of soilborne diseases}

Both incidence and severity of common root rot for all years (1989-96) were inversely related to the amount of available water at sowing (including annual medic-wheat and chickpea-wheat); irrespective of crop rotations (Fig. 3a). For example, incidence and severity decreased from $39 \%$ at $100 \mathrm{~mm}$ to $15 \%$ at $200 \mathrm{~mm}$ of plant available water $(0-1.2 \mathrm{~m}$ depth). Pre-sowing nitrate-N in these rotations was not significantly related to the severity of common root rot in wheat (Fig. $3 b$ ).

Since plant available water at sowing was generally lower in lucerne-wheat rotation than wheat-wheat rotation, common root rot occurrence was usually higher in the former. Other soilborne diseases, crown rot and root lesion nematode, were either absent or very low in this experiment. Reeves et al. (1984) and Wildermuth et al. (1997) observed the disease-break effects of legumes in rotation with wheat

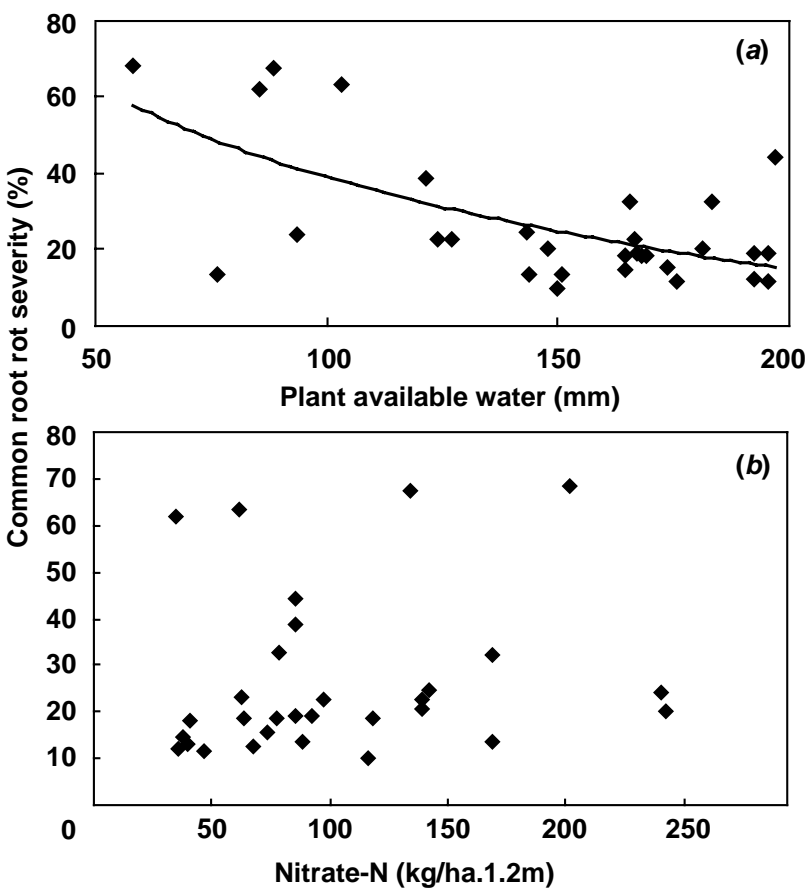

Figure 3. Relationship between the severity (\%) of common root rot of wheat and $(a)$ plant available water and $(b)$ nitrate-N in soil $(0-1.2 \mathrm{~m})$ at sowing from 1989 to 1996. Rotations were: lucerne-wheat, annual medics-wheat (Weston et al. 2002), chickpea-wheat (Dalal et al. 1998), and wheat-wheat with 0 and $50 \mathrm{~kg} \mathrm{~N} / \mathrm{ha} \mathrm{(1989} \mathrm{and} 1996$ only) application (Strong et al. 1996). The equation of the line in $(a)$ is:

$$
y=-34.8 \log _{\mathrm{e}}(x)+199.1\left(R^{2}=0.4\right) .
$$


when plant available water, including in-crop rainfall, was either similar or higher than wheat-wheat rotations.

In summary, besides wheat yields and protein benefits following lucerne ley, lucerne-wheat rotations maintained similar soil $\mathrm{N}$ levels at the end of the experiment (Fig. 1) compared with the decline in soil total $\mathrm{N}$ in chickpea-wheat rotation (Dalal et al. 1998). Holford et al. (1998) also obtained similar results although the periods of lucerne leys in their experiments (Holford and Doyle 1978; Holford 1980; Holford et al. 1998) were longer (1.5-6.75 years) than the 4 cycles of 1 -year lucerne ley in this study.

\section{Conclusion}

The lucerne-wheat rotation provides an attractive option for restoring the fertility of $\mathrm{N}$-depleted soils and sustaining wheat yields in the eastern subtropical region of the Australian cereal belt. The main benefits from lucerne in lucerne-wheat rotations were due to $\mathrm{N}$ accretion rather than disease-break; provided good amounts of stored soil water and growing season rainfall occurred. In low rainfall seasons, however, wheat yields in lucerne-wheat rotations are depressed and grain protein levels are elevated (due to higher nitrate- $\mathrm{N}$ concentrations). They are often above $15 \%$, resulting in lower wheat yields, higher yield variability, and smaller seed size; as compared with wheat-wheat rotations with moderate and targeted fertiliser $\mathrm{N}$ applications. This may have been due to short lucerne ley (1 year) in lucerne-wheat rotation, thus, not allowing a long enough period to recharge the soil water profile to field capacity before wheat sowing in this subtropical environment. We report in a subsequent paper the effect of various durations of lucerne leys (1-4 years) on $\mathrm{N}$ benefits and yields of following wheat crops from this experiment (Dalal et al. 2004).

\section{Acknowledgments}

We thank Mr Peter Bock and Mr Tim Reid for providing land for the Warra Experiment, Queensland Wheat Committee and Grains Research and Development Corporation for the funding support, and Mrs J Glasby and Mrs A Pumfrey for analytical analysis.

\section{References}

Armstrong RD, McCosker K, Johnson SB, Walsh KB, Millar G, Kuskopf B, Standley J, Probert ME (1999) Legume and opportunity cropping systems in central Queensland. 1. Legume growth, nitrogen fixation, and water use. Australian Journal of Agricultural Research 50, 909-924. doi:10.1071/AR98100

Best EK (1976) An automated method for the determination of nitrate-nitrogen in soil extracts. Queensland Journal of Agricultural and Animal Sciences 33, 161-166.

Crooke WM, Simpson WE (1971) Determination of ammonium in Kjeldahl digests of crops by an automated procedure. Journal of the Science of Food and Agriculture 22, 9-10.

Dalal RC, Mayer RJ (1986a) Long-term trends in fertility of soils under continuous cultivation and cereal cropping in southern Queensland. 1. Overall changes in soil properties and trends in winter cereal yields. Australian Journal of Soil Research 24, 265-279.
Dalal RC, Mayer RJ (1986b) Long-term trends in fertility of soils under continuous cultivation and cereal cropping in southern Queensland. II. Total organic carbon and its rate of loss from the soil profile. Australian Journal of Soil Research 24, 281-292.

Dalal RC, Mayer RJ (1987) Long-term trends in fertility of soils under continuous cultivation and cereal cropping in southern Queensland. VII. Dynamics of nitrogen mineralisation potentials and microbial biomass. Australian Journal of Soil Research 25, 461-472.

Dalal RC, Probert ME (1997) Soil nutrient depletion. In 'Sustainable crop production in the sub-tropics: an Australian perspective'. (Eds AL Clarke, PB Wylie) pp. 42-63. (Department of Primary Industries: Brisbane)

Dalal RC, Sahrawat KL, Mayer RJ (1984) Inclusion of nitrate and nitrite in the Kjeldahl nitrogen determination of soils and plant materials using sodium thiosulphate. Communications in Soil Science and Plant Analysis 13, 75-86.

Dalal RC, Strong WM, Doughton JA, Weston EJ, McNamara GT, Cooper JE (1997a) Sustaining productivity of a Vertosol at Warra, Queensland, with fertiliser, no-tillage or legumes. 4. Nitrogen fixation, water use and yield of chickpea. Australian Journal of Experimental Agriculture 37, 667-676.

Dalal RC, Strong WM, Weston EJ, Cooper JE, Lehane KJ, King AJ, Chicken CJ (1995) Sustaining productivity of a Vertosol at Warra, Queensland, with fertiliser, no-tillage, or legumes. 1. Organic matter status. Australian Journal of Experimental Agriculture 35, 903-913.

Dalal RC, Strong WM, Weston EJ, Cooper JE, Thomas GA (1997b) Prediction of grain protein in wheat and barley in a subtropical environment from available water and nitrogen in Vertosols at sowing. Australian Journal of Experimental Agriculture 37, 351-357.

Dalal RC, Strong WM, Weston EJ, Cooper JE, Wildermuth GB, Lehane KJ, King AJ, Holmes CJ (1998) Sustaining productivity of a Vertosol at Warra, Queensland, with fertilisers, no-tillage, or legumes. 5. Wheat yields, nitrogen benefits and water-use efficiency of chickpea-wheat rotation. Australian Journal of Experimental Agriculture 38, 489-501.

Dalal RC, Strong WM, Weston EJ, Gaffney J (1991) Sustaining multiple production systems. 2. Soil fertility decline restoration of cropping lands in sub-tropical Queensland. Tropical Grasslands 25, $173-180$.

Dalal RC, Weston EJ, Strong WM, Lehane KJ, Cooper JE, King AJ, Holmes CJ (2004) Sustaining productivity of a Vertisol at Warra, Queensland, with fertiliser, no-tillage and legumes. 8. Effect of variable duration of lucerne ley on measured and simulated soil nitrogen and water, wheat yield and protein. Australian Journal of Experimental Agriculture 44, (in press).

Doughton JA, Vallis I, Saffigna PG (1993) Nitrogen fixation in chickpea. 1. Influence of prior cropping or fallow, nitrogen fertiliser and tillage. Australian Journal of Agricultural Research 44, 1403-1413.

Hallsworth EG, Gibbons FR, Lemerle TH (1954) The nutrient status and cultivation practices of soils of the north-west wheat belt of New South Wales. Australian Journal of Agricultural Research 5, 65-73.

van Herwaarden AF, Farquhar GD, Angus JF, Richards RA, Howe GN (1998) 'Haying-off', the negative grain yield response of dryland wheat to $\mathrm{N}$ fertilizer. 1. Biomass, grain yield, and water use. Australian Journal of Agricultural Research 49, 1067-1081.

Holford ICR (1980) Effects of duration of grazed lucerne on long-term yields and nitrogen uptake of subsequent wheat. Australian Journal of Agricultural Research 31, 239-250. 
Holford ICR (1981) Changes in nitrogen and organic carbon of wheat-growing soils after various periods of grazed lucerne, extended fallowing and continuous wheat. Australian Journal of Soil Research 19, 239-249.

Holford ICR, Crocker GJ (1997) A comparison of chickpeas and pasture legumes for sustaining yields and nitrogen status of subsequent wheat. Australian Journal of Agricultural Research 48, 305-315.

Holford ICR, Doyle AD (1978) Effect of grazed lucerne on the moisture status of wheat-growing soils. Australian Journal of Experimental Agriculture and Animal Husbandry 18, 112-117.

Holford ICR, Doyle AD (1992) Yield responses and nitrogen fertilizer requirements of wheat in relation to soil nitrate levels at various depths. Australian Journal of Soil Research 30, 683-694.

Holford ICR, Schweitzer BE, Crocker GJ (1998) Comparative effects of subterranean clover, medic, lucerne, and chickpea in wheat rotations, on nitrogen, organic carbon, and moisture in two contrasting soils. Australian Journal of Soil Research 36, 57-72.

Hossain SA, Dalal RC, Waring SA, Strong WM, Weston EJ (1996a) Comparison of legume-based cropping systems at Warra, Queensland. I. Soil nitrogen and organic carbon accretion and potentially mineralisable nitrogen. Australian Journal of Soil Research 34, 273-287.

Hossain SA, Strong WM, Waring SA, Dalal RC, Weston EJ (1996b) Comparison of legume-based cropping systems at Warra, Queensland. II. Mineral nitrogen accumulation and availability to subsequent wheat crop. Australian Journal of Soil Research 34, 289-297.

Hossain SA, Waring SA, Strong WM, Dalal RC, Weston EJ (1995) Estimates of nitrogen fixations by legumes in alternate cropping systems at Warra, Queensland, using enriched- ${ }^{15} \mathrm{~N}$ dilution and natural ${ }^{15} \mathrm{~N}$ abundance techniques. Australian Journal of Agricultural Research 46, 493-505.

Ledgard SF, Peoples MB (1988) Measurements of nitrogen fixation in the field. In 'Advances in nitrogen cycling in agricultural ecosystems'. (Ed. JR Wilson) pp. 351-367. (CAB International: Wallingford, UK)

Littler JW (1984) Effect of pasture on subsequent wheat crops on a black earth soil of the Darling Downs. I. The overall experiment. Queensland Journal of Agriculture and Animal Sciences 41, 1-12.

Lloyd DL, Hilder TB (1978) 'Growth of lucerne in relation to soil water. Queensland Wheat Research Institute Biennial Report 1976-1978.' Queensland Department of Primary Industries, Toowoomba. p. 41

Peoples MB, Baldock JA (2001) Nitrogen dynamics of pastures: nitrogen fixation inputs, the impact of legumes on soil nitrogen fertility, and the contributions of fixed nitrogen to Australian farming systems. Australian Journal of Experimental Agriculture 41, 327-346. doi:10.1071/EA99139
Peoples MB, Bowman AM, Gault RR, Herridge DF, McCallum MH, McCormick KM, Norton RM, Rochester IJ, Scammell GJ, Schwenke GD (2001) Factors regulating the contributions of fixed nitrogen by pasture and crop legumes to different farming systems of eastern Australia. Plant and Soil 228, 29-41. doi:10.1023/A:1004799703040

Strong WM, Dalal RC, Weston EJ, Cooper JE, Lehane KJ, King AJ, Chicken CJ (1996) Sustaining productivity of a Vertosol at Warra, Queensland, with fertiliser, no-tillage and legumes. 2. Long-term fertiliser needs to enhance wheat yields and grain protein. Australian Journal of Experimental Agriculture 36, 665-674.

Waring SA, Bremner JM (1964) Ammonium production in soil under waterlogged conditions as an index of $\mathrm{N}$ availability. Nature 201, 951-952.

Weston EJ, Dalal RC, Strong WM, Lehane KJ, Cooper JE, King AJ, Holmes CJ (2002) Sustaining productivity of a Vertosol at Warra, Queensland, with fertiliser, no-tillage and legumes. 6. Production and nitrogen benefits from annual medic in rotation with wheat. Australian Journal of Experimental Agriculture 42, 665-674. doi:10.1071/EA02004

Weston EJ, Doughton JA, Dalal RC, Strong WM, Thomas GA, Lehane KJ, Cooper JC, King AJ, Holmes CJ (2000) Managing long-term fertility of cropping lands with ley pastures in southern Queensland. Tropical Grasslands 34, 169-176.

Whitehouse MJ, Littler JW (1984) Effect of pasture on subsequent wheat crops on a black earth soil of the Darling Downs. II. Organic $\mathrm{C}$, nitrogen and $\mathrm{pH}$ changes. Queensland Journal of Agriculture and Animal Sciences 41, 13-20.

Wildermuth GB, Tinline AD, McNamara RB (1992) Assessment of yield loss caused by common root rot in wheat cultivars in Queensland. Australian Journal of Agricultural Research 43, 43-58.

Wildermuth GB, Thompson JP, Robinson LN (1997) Biological change: diseases, insects and beneficial organisms. In 'Sustainable crop production in the sub-tropics: an Australian perspective'. (Eds AL Clarke, PB Wylie) pp. 112-130. (Department of Primary Industries: Brisbane)

Received 14 July 2002, accepted 10 October 2003 